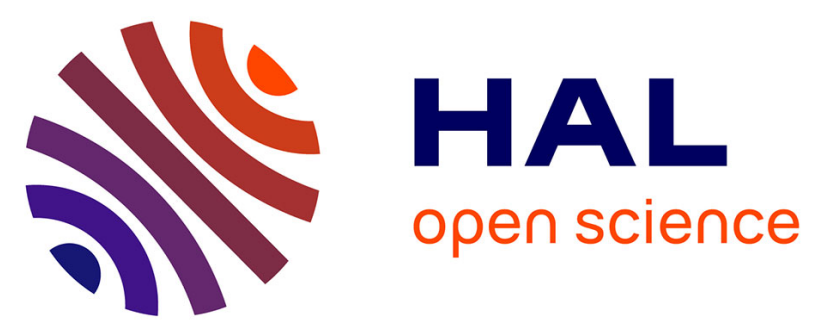

\title{
LOW POWER LASER BEAM PROFILE ANALYSIS BY DIGITAL PHOTOGRAPHIC TECHNIQUE
}

\author{
F. Sendra, J. Pastor, E. Fernández Vicioso, A.J. García de Linares, A. Díez de
} Los Ríos, M. Martínez Morillo

\section{- To cite this version:}

F. Sendra, J. Pastor, E. Fernández Vicioso, A.J. García de Linares, A. Díez de Los Ríos, et al.. LOW POWER LASER BEAM PROFILE ANALYSIS BY DIGITAL PHOTOGRAPHIC TECHNIQUE. Journal de Physique IV Proceedings, 1991, 01 (C7), pp.C7-741-C7-744. 10.1051/jp4:19917199 . jpa00250879

\section{HAL Id: jpa-00250879 https://hal.science/jpa-00250879}

Submitted on 1 Jan 1991

HAL is a multi-disciplinary open access archive for the deposit and dissemination of scientific research documents, whether they are published or not. The documents may come from teaching and research institutions in France or abroad, or from public or private research centers.
L'archive ouverte pluridisciplinaire HAL, est destinée au dépôt et à la diffusion de documents scientifiques de niveau recherche, publiés ou non, émanant des établissements d'enseignement et de recherche français ou étrangers, des laboratoires publics ou privés. 


\title{
LOW POWER LASER BEAM PROFILE ANALYSIS BY DIGITAL PHOTOGRAPHIC TECHNIQUE
}

\section{F. SENDRA, J.M. PASTOR, E. FERNÁNDEZ VICIOSO, A.J. GARCÍA de LINARES,} A. DÍEZ de los RÍOS* and M. MARTÍNEZ MORILLO

Cátedra de Radiología y Medicina Física, Facultad de Medicina, Universidad de Málaga, Campus Universitario de Teatinos, SP-29080 Málaga, Spain

*Cátedra de Fúsica Médica, Facultad de Medicina, Universidad de Málaga, Campus Universitario de Teatinos, SP-29080 Málaga, Spain

\begin{abstract}
Laserbeam profile is animportant physical parameter which is often not taken into account.

We describe a photographic technique to study Helium-Neon (HeNle) laser beam profile, testing different film sensitivities.

When laser beam strikes directly towards the camera lens, several pictures were taken at differem exposition times.

Negative images of laserbeam spot were recorded using a video camera with atrasillumination setop thatched to ananalogyc-digital convertertobecomputed.

Laser spor diameter profiles were scanned, and the results were plotted (grey levels against beam size).

The results were normalized to the film grossfog, and Gawsian behaviours were found as exspected.

The same procedure was repeated using different films with different sensitivities, trying to select the mare suitable film for our laser power.

This technique is also useful to study infrared wavelenghs beam profiles, and other low power lasers, choosing theoptimalfilms.

Laser beam inhomogeneities can be detected, and mixed medical lasers can be checked.

It is also possible to stody the emergent light through different thickness tissue slices.
\end{abstract}

\section{INTRODUCTION}

Laser beam profile is an important parameter which is often not taken into account. The majoc reason is that beam characterisation use to be atedious and expensive task.

Several methods has been employed to measure spot size and gavssian profiles of laser beams using a knifeedge (1), an aperture (2), a slit (3), or a ribbon (4). All these methods have certain technical similarity wich consists of realize a direct lecture (frecuently slow) of the laser beam with a more or less complex system of aperture or collimation.

Images of the laser beam spot can be used to characterize the spot sizes, intensities and spatial pauterns. Some techniques has been described using video cameras $(5,6)$.

Photographic emulsions are a detectionsystem used in mmerows scientific fields. We present a tehcrique which allows to stody HeNe and other low power laser beam profiles. 


\section{TECHNIQUE}

In a single point of view our technique consists of take photographies of the laser beam when it strikes directly towards the camera lens. With this purpose a Nikon camera mod EG-20 and a suitable macro lens with a polarizer fitter were used. Both laser unit and camera were placed on an optical bench, and aligned with the laser beam axis. A picture of a millimetered paper sheet was taken in order to have a reference for scaling.

Once developed, the negatives were placed over a light box and transilluminated. Then the image of laser beam spot was recorded using an RCA video camera which is thutched to an analogyc-digital converter IBAS 2000 Image processing system (IPS) to be computed.

Images were registered in a matrix of $512 \times 512$ pizels with a range of 256 grey levels (GL) between 0 GL(blact) and $255 \mathrm{GL}$ (white).

Profiles (beam size agains GL) could be plotted, and grossfog GL gould be determined by means of an unexposed sheet of film.

\section{HELIUM-NEON PROPLLS}

Several probes were done with three HeNe lasers (632 nm wavelengh) of $0.5 \mathrm{~mW}, 6 \mathrm{~mW}$ and $12.6 \mathrm{~mW}$ power. Ilford black and white films of 50,125 and 400 ASA were used. Results were very poor. Even with the less sensible film, the shorter exposure times and lower power beam, spot images presented a considerable halo.

A slower emulaion (Rodalith ortho film 6556) gave us more satisfactory results with the aditional adventage to be a high contrast film, giving less problems of autoabsorption.

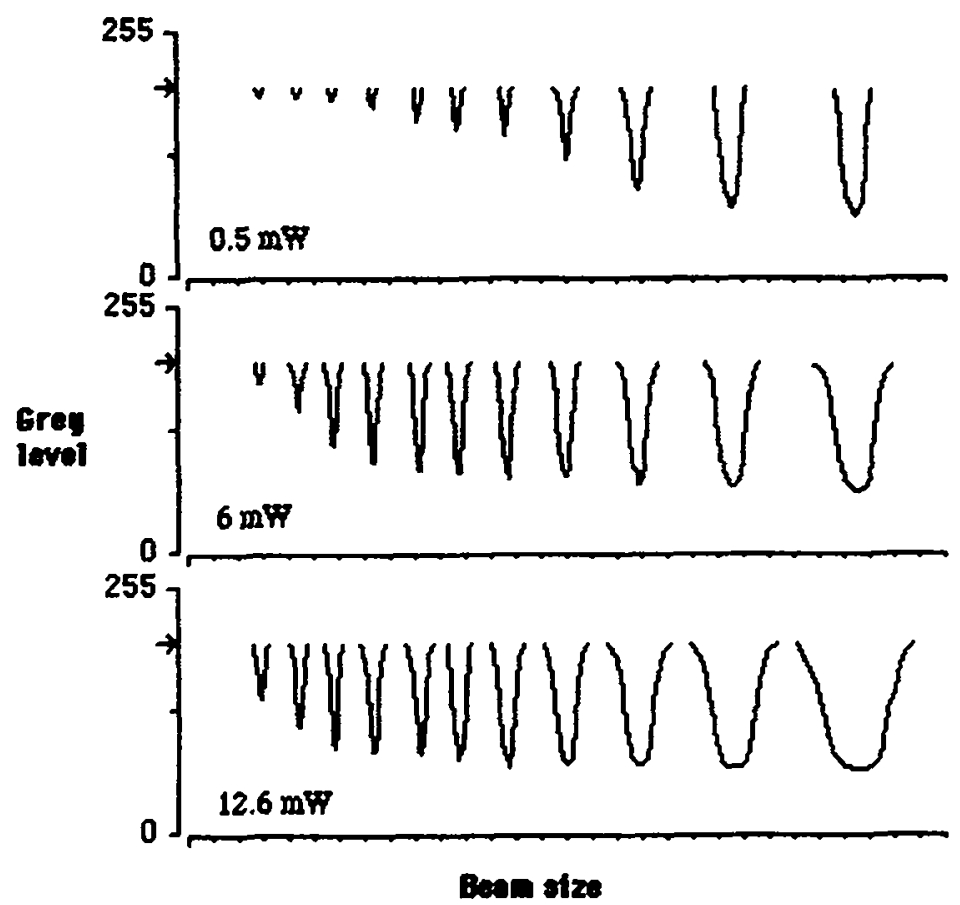

Fig. 1. HeNe beam profiles taken with different exposure times, from 1/1000 doobling successively to 1s. Film: Kodalith ortho film 6556. Beam size axis marts: $5 \mathrm{~mm}$. Grossfog $196 \mathrm{GL}$ (arrw). 
Phowographies of the laser beams were taken at different exposure times, doubling soccesvively from $1 / 1000$ to 1 second.Focos was fixed at F4. Narrow Gaussian Profiles were obtained as described before and they are presented in Fig. 1.

As photography is a static collecter of light photons the wideness of profiles size increases with the exposure time and light intensity. It can be seen that under $1 / 30 \mathrm{~s}$ exposureprofiles wideness measure less than $5 \mathrm{~mm}$ which is close to the real size of the beam. A proportion between the beam intensity and profiles depht can be find only until $1 / 500$ s exposure.

\section{NTRARED PROFIL.ES}

Infrared wavelenghs can be studied choosing the optimal film. A similar study than the described above for HeNe laser, with the same experiemtal set op has been made with Galium-Arsenide (GaAs) with $904 \mathrm{~nm}$ wavelengh, pulsed at $0.5 \mathrm{KHz}$ and $5 \mathrm{KHz}(0.26$ and $2.6 \mathrm{~mW}$ mean power).

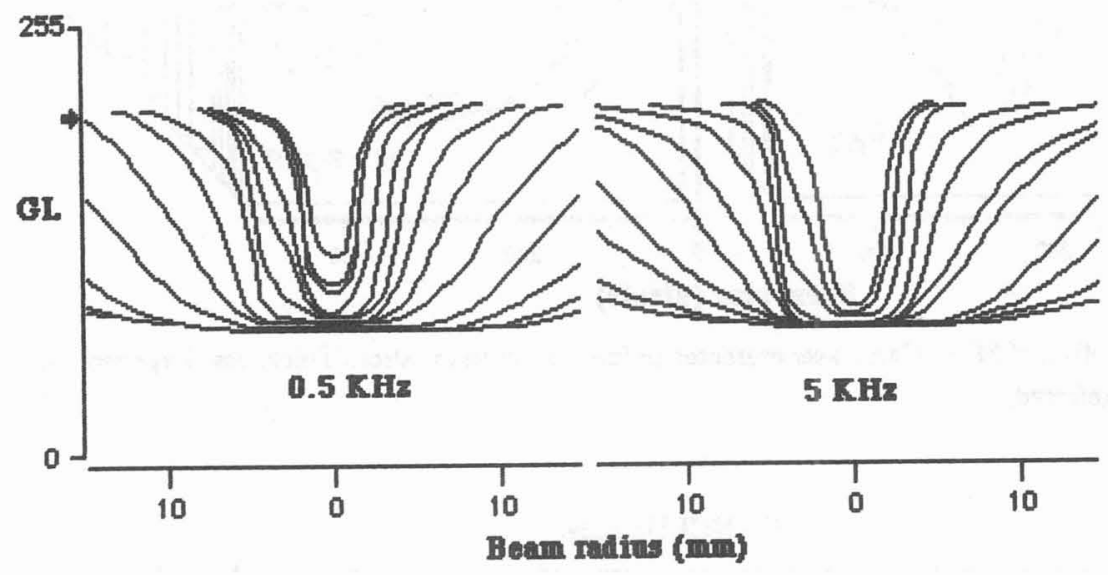

Fig.2. GaAs laser beam profiles taken with different exposure times, from $1 / 1000$ doubling swccessively to $1 \mathrm{~s}$. Grossfog $190 \mathrm{GL}$ (arrow).

The film used was High Speed infrared 2481 (Kodak). Laser beam profiles were studied with identical procedure as before. Results are plotted in Fig.2. While profiles of $0.5 \mathrm{KHz}$ beam reach satormion at $1 / 125 \mathrm{~s}$ exposure, $5 \mathrm{Khz}$ beam profiles reach it at $1 / 500$ s exposure.

Some irregularities can be seen in profiles due to the own beam inhomogeneity

Taking into account that HeNe lasers use to have too much intensity for this film, High Speed Infrared may be used toeasily check mired medical laser equipemems.

\section{LASER-TISSUE NTERACTION}

Phocography has been proposed as a suitable method to measure isodose distibutions of space irradiance in phantoms and fresh cow muscle (6).

With this technique photographies can be taken from the reverse slab when it is transilluminated with a laser beam. Scatteringandattemuation can be studied by means of size, shape and intensity of several beam spots at different tissue thickness. Even more, increasing the exposure time lower intensities, deeper into the tissue can be stodied. 
In Fig. 3 profiles of $5 \mathrm{KHz}$ GaAs laser are presented in function of tissue thicteness for pig muscle and fat . The exposure time selected was 20 seconds.

It can be easily seen the differen behaviour with fat tissue, with less scattering centers than muscle, where profiles show a wide size spetially at first millimeters depth.

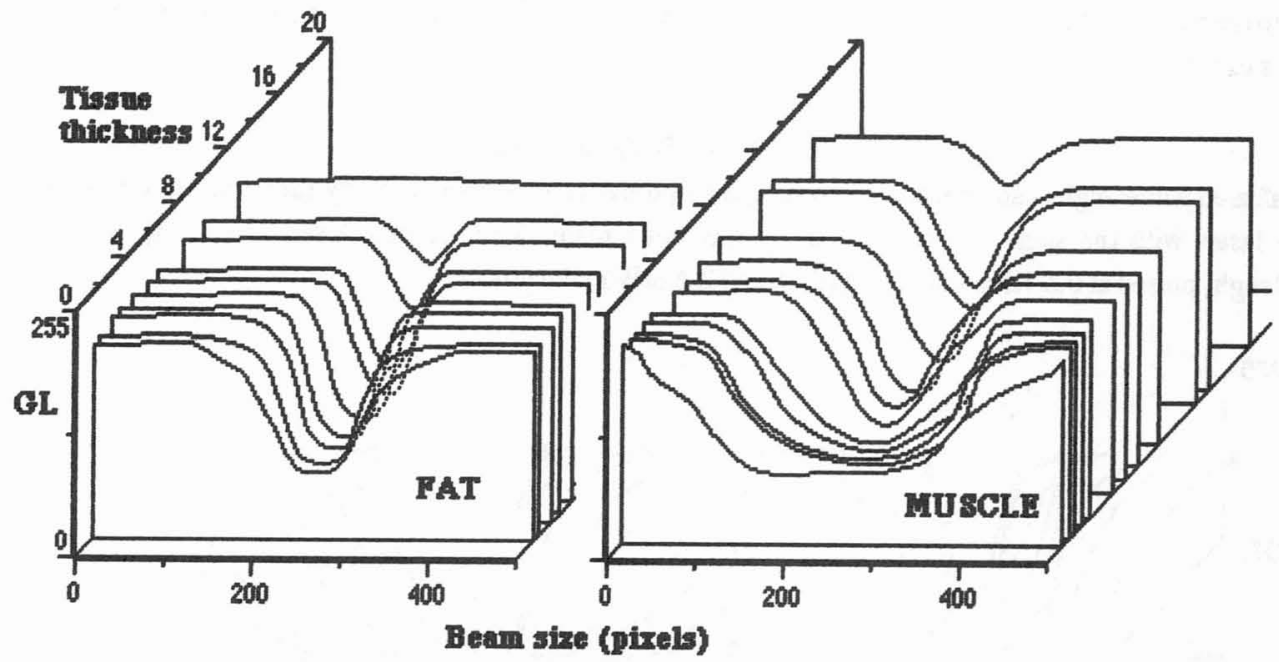

Fis.3. Beam profiles of $5 \mathrm{KHz}$ GaAs laser presented in function of tissue slices Thictoness. Exposure time: 20 s. Film: High Speed infrared.

\section{CONCLUSIONS}

Digitized photography is a method wich allows to measure and stody low power laser beam behaviour once selected the adequatephotographicemulsion.

Laser-tissuinteraction can be studied an relationed with laser beam intensity. Pictures can be also made from different points than tha farward one.

Photographies are a permanent image support wich can be re-stodied if the digital processing system is performed or substituted and retrospective comparisons between systems and softward can be made.

\section{REFERENCES}

I. SKINER, D.R. and WITCHER, R. E. J. Phys. E. 5 (1972) 237 -

2. SHAYLER, P.J. Appl. Opt. 17 (1978)2673-.

3. McCALLY, R.L. Appl. Opt. 23 (1984) 2227-

4. YOSHIDA, A and ASAKURA, T. A. Opt. Leser Technol. 8 (1976) $273-$.

5. NISHIOKA, N.S., BUA, D.P. and DEUTSCH, T.F. Lasers Med. Sci. 2 (1987) 21 -.

6. DUNCAN, M.D. and MAHON, R. Appl. Opt. 28 (1989) 4569.

7. McKENZIE, A.L. and BYRNE, P.O. Phys. Med. Biol. 33 (1988) $113-$. 
In Fig. 3 profiles of $5 \mathrm{KHz}$ GaAs laser are presented in function of tissue thicteness for pig muscle and fat . The exposure time selected was 20 seconds.

It can be easily seen the differen behaviour with fat tissue, wibt less scattering centers than muscle, where profiles show a wide size spetially at first millimeters depth.

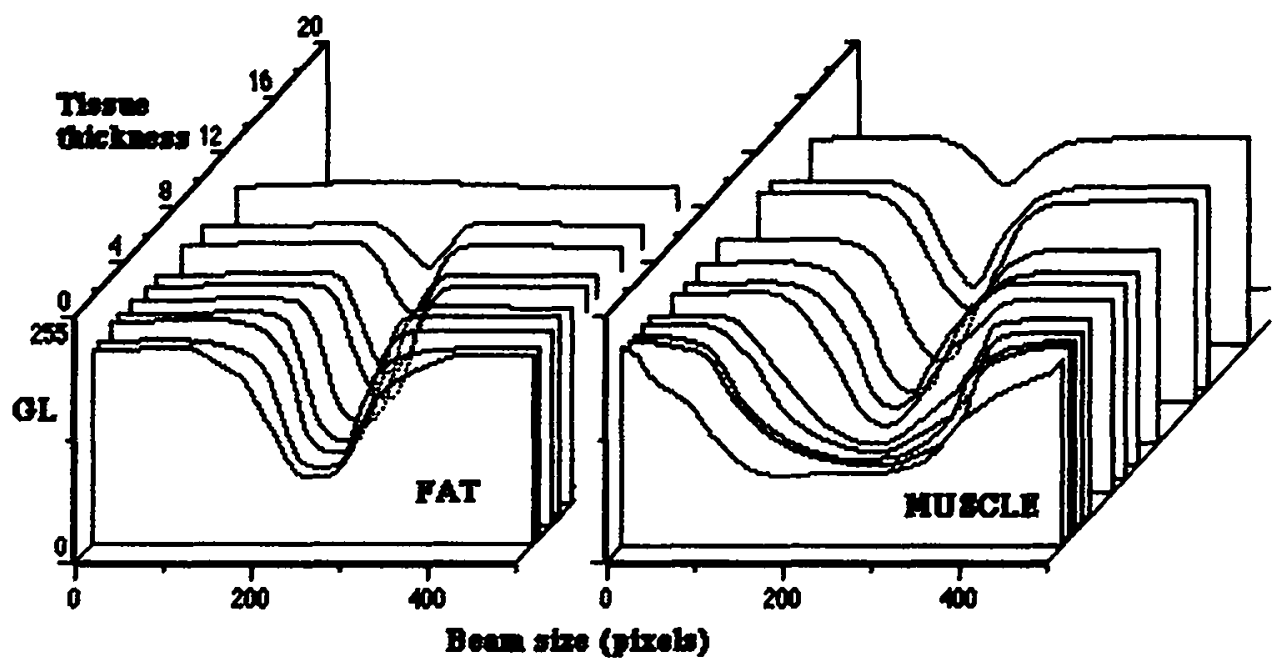

Fis.3. Beam profiles of $5 \mathrm{KHz}$ GaAs laser presented in function of tissue slices Thictoness. Expossure time: 20 s. Film: High Speed infrared.

\section{CONCLUSIONS}

Digitized photography is a method wich allows to measure and stody low power laser beam behaviour once selectedtheadequatephotographicemulsion.

Laser-tissueinteraction can be stodied an relationed with laser beam intensity. Pictures can be also made from different points than tha forward one.

Photographies are a permanent image suppont wich can be re-stodied if the digital processing system is performed or substituted and retrospective comparisons between systems and softward can be made.

\section{REFERENCES}

I. SKINER, D.R. and WITCHER, R.E. J. Phys. E. 5 (1972) 237 -

2. SHAYLER, P.J. Appl. Opt. 17 (1978) 2673-.

3. MCCALLY, R.L. App1. Opt. 23 (1984) 2227-

4. YOSHIDA, A and ASAKURA, T. A. Opt Laser Technol. 8 (1976) $273-$.

5. NISHIORA, N.S., BUA, D.P. and DEUTSCH, T.F. Lasers Med. Sci. 2 (1987) 21 -.

6. DUNCAN, M.D. and MAHON, R. Appl. Opt 28 (1989) 4569 .

7. McKENZIE, A.L. and BYRNE, P.O. Phys. Med. Biol. 33 (1988) $113-$. 